\title{
AGROSAINSTEK
}

Jurnal Ilmu dan Teknologi Pertanian

Website jurnal : http://journal.ubb.ac.id/index.php/agrosainstek

Artikel Penelitian

\section{Uji Efikasi Ekstrak Daun Mengkudu, Kemangi dan Jambu Biji dalam Menghambat Pertumbuhan Cendawan Colletotrichum gloeosporioides pada Buah Pepaya}

\section{Efficacy Testing The Extracts of Noni Leaf, Basil Leaf, and Guava Leaf in Inhibiting the Growth of Colletrotrichum gloesporioides in Papaya}

\author{
Sari Susanti 1* , Riwan Kusmiadi1 ${ }^{\text {, Sitti Nurul Aini1 }}{ }^{1}$ \\ 1 Jurusan Agroteknologi, Fakultas Pertanian, Perikanan, dan Biologi, Universitas Bangka Belitung. Jl. \\ Raya Balunijuk, Bangka 33215
}

Diterima : 13 Juli 2016/Disetujui : 2 Desember 2016

\begin{abstract}
Anthracnose disease is a crucial problem in the cultivation of papaya. It is caused by C.gloesporioides. one way to overcome this problem was by using natural fungicides. Some of the natural substances that have natural fungicides as their property are noni, basil, and guava. The research was conducted at the Microbiology laboratory of the Faculty of Agriculture, Fisheries, and Biology of Universitas Bangka Belitung January to April 2016. The research utilizes Randomized Analysis Complete Design with Factorial structure. The first factor are the extracts (E), consists of noni leaves (E1), basil leaves (E2), and guava leaves (E3). The second factor are the concentrations of the extract, consists of 0\% (K0), 10\% (k1), 20\% (K2), 30\% (K3), 40\% (K4), 50\%(K5), and 60\% (K6). The data was analysed using analysis of variance at $\alpha$ 5\%, with the used of SAS Program (Statistical Analytic System), if the effect was found significant, the data was further analysed using DMRT (Duncan Multiple Range Test). The research result showed that the extract of guava leaves at 30\% consentration provided the best result in inhibiting the growth of C.gloesporioides in papaya.
\end{abstract}

Keywords : Anthracnose, C. gloesporioides, papaya, leaves extract of noni, basil, guava.

ABSTRAK

Penyakit antraknosa merupakan salah satu masalah penting dalam budidaya pepaya, yang disebabkan oleh C.gloesporioides. Salah satu cara penanggulangannya menggunakan fungisida nabati. Bahan alami yang mempunyai khasiat sebagai fungisida nabati adalah mengkudu, kemangi dan jambu biji. Penelitian dilakukan dilaboratorium Mikrobiologi Fakultas Pertanian, Perikanan, dan Biologi Universitas Bangka Belitung pada bulan Januari sampai April 2016. Penelitian menggunakan Rancangan Acak Lengkap Faktorial (RALF), faktor pertama ekstrak (E) yaitu ekstrak daun mengkudu (E1), kemangi (E2) dan jambu biji (E3), faktor kedua yaitu konsentrasi yaitu 0\% (K0), 10\% (K1), 20\% (K2), 30\% (K3), 40\% (K4), 50\% (K5) dan 60\% (K6). Data dianalisis menggunakan analisis varian pada $\alpha 5 \%$ dengan menggunakan program SAS (Statistical Analitic System), jika berpengaruh nyata dilakukan uji lanjut DMRT (Duncan Multiple Range Test). Hasil penelitian menunjukkan ekstrak daun jambu biji konsentrasi $30 \%$ paling baik menghambat pertumbuhan C.gloesporioides pada buah pepaya.

Kata kunci : Antraknosa, C. gloesporioides, pepaya, Ekstrak daun mengkudu, kemangi, jambu biji. 


\section{Pendahuluan}

Penyakit antraknosa merupakan salah satu masalah penting dalam budidaya pepaya, yang disebabkan oleh C.gloesporioides. Penyakit ini biasanya sering menyerang pepaya di musim hujan. Antraknosa lebih dikenal sebagai penyakit pasca panen atau penyakit gudang (Hafsah 2007).

Teknik pengendalian banyak diterapkan petani di lapangan dalam mengendalikan penyakit antraknosa masih mengarah pada penggunaan fungisida sintesis yang residu bahan aktifnya dapat bertahan pada buah pascapanen sehingga dapat membahayakan manusia yang mengkonsumsinya (Indriyani 2008). Salah satu alternatif untuk meminimalkan risiko penggunaan fungisida sintetis adalah menggunakan fungisida nabati (Nazirah 2011). Bahan alami yang diduga mempunyai khasiat sebagai fungisida nabati adalah mengkudu (Morinda citrifolia L.), kemangi (Ocimum basilicum L.) dan jambu biji (Psidium guajava Linn).

Tanaman mengkudu (Morinda citrifolia L.) khususnya daun mengandung zat kapur, protein, zat besi, karoten, arginin, asam glutamat, tirosin, asam askorbat, asam ursolat, thiamin, dan antrakuinon. Selain itu menurut Rahmawati (2009), pada daun mengkudu juga terkandung glikosida iridoid, glikosida flavonoid dan triterpen. Kandungan flavonoid total dalam daun mengkudu adalah $254 \mathrm{mg} / 100 \mathrm{~g}$. Kandungan flavonoid dan antraquinon yang terkandung dalam daun mengkudu dipercaya aktif sebagai antimikroba.

Tanaman kemangi (Ocimum basilicum L.) terutama daun, mengandung senyawa flavonoid, saponin, triterpenoid/steroid, alkaloid serta minyak atsiri dengan eugenol. Eugenol dan flavonoid yang terkandung pada daun kemangi juga dipercaya memiliki efek antimikroba (Medica et al. 2004).

Tanaman Jambu Biji (Psidium guajava Linn) merupakan tanaman yang banyak dimanfaatkan masyarakat sebagai obat. Bagian tanaman yang sering digunakan sebagai obat adalah daunnya, karena daunnya diketahui mengandung senyawa tanin, flavonoid, saponin, alkaloid, minyak atsiri, minyak lemak dan asam malat (Depkes 1989).

Salah satu senyawa aktif yang terkandung pada daun jambu biji adalah tanin sebesar 9-12\% yang memiliki daya anti septik yaitu mencegah kerusakan yang disebabkan bakteri atau jamur (Yuliani et al. 2003). Senyawa tanin yang memiliki

*Korespondensi Penulis.

E-mail: sarysusanti@yahoo.co.id (S. Susanti) rasa pahit mampu menghambat pertumbuhan mikroorganisme, menyerap racun dan dapat menggumpalkan protein (Heyne 1987).

Dari masalah diatas maka perlu dilakukan penelitian untuk melihat pengaruh ektrak daun mengkudu, kemangi dan jambu biji dalam menghambat pertumbuhan C.gloesporioides pada buah pepaya (Carica papaya L.).

\section{Bahan dan Metode}

\section{Bahan}

Bahan yang digunakan buah pepaya yang terserang penyakit, daun mengkudu, daun kemangi, daun jambu biji, media Potato Dextrose Agar (PDA), lactofenol cotton blue, minyak imersi, alkohol 70\% dan aquades.

\section{Isolasi dan Identifikasi Cendawan}

Buah yang sakit disteril dengan disemprotkan alkohol 70\% kemudian dikeringkan dengan tisu steril (Nugraheni et al. 2014). Jaringan antara buah yang sakit dan sehat dipotong kemudian diisolasi dengan meletakkannya pada cawan petri berisi media PDA dan diinkubasi pada suhu $28^{\circ} \mathrm{C}$ sampai tumbuh (Rani et al. 2013). Cendawan yang tumbuh dimurnikan dan diidentifikasi. Hasil identifikasi kemudian diperbanyak pada media PDA (Nugraheni et al. 2014).

\section{Uji Patogenisitas (Postulat Koch)}

Buah pepaya yang sehat dibersihkan dengan aquades steril kemudian dikeringkan dengan tisu lalu disteril dengan tisu yang mengandung alkohol $70 \%$. Pada setiap permukaan buah yang sehat dilukai kemudian ditempelkan isolat cendawan setelah itu tutup dengan selotip. Buah pepaya ditempatkan pada baki yang dibawahnya telah dilapisi dengan tisu basah dan sedotan minuman, kemudian dibungkus dengan plastik wrafing dan dinkubasi pada suhu ruang $\left(28^{\circ} \mathrm{C}\right)$ sampai terlihat gejala kerusakan ( \pm 7 hari) (Hafsah 2005).

Pembuatan media PDA + Ektrak Daun Mengkudu, Kemangi dan Jambu biji

Komponen media pembuatan PDA dicampurkan dengan ekstrak daun mengkudu, kemangi dan jambu biji dengan konsentrasi yang berbeda-beda yaitu $10 \%, 20 \%, 30 \%, 40 \%, 50 \%, 60 \%$ serta tambahkan aquades hingga volume $250 \mathrm{~mL}$ kemudian aduk diatas Hot Plate dengan menggunakan magnetic stirrer hingga homogen, angkat, tutup dengan alumunium foil dan sterilisasi kedalam autoklaf dengan suhu $121{ }^{\circ} \mathrm{C}$ selama 15 menit (Nugroho 1999). 
Uji Efikasi Ekstrak Daun Mengkudu, Kemangi dan Jambu biji terhadap Pertumbuhan C.gloesporioides

Isolat cendawan C.gloesporioides ditumbuhkan pada media PDA yang mengandung ekstrak daun mengkudu, kemangi dan jambu biji dengan masing - masing konsentrasi 10\%, 20\%, 30\%, 40\%, 50\%, $60 \%$ dan kontrol (0\%). Selanjutnya biakan diinkubasi sampai koloni cendawan memenuhi cawan pada suhu $28{ }^{\circ} \mathrm{C}$. Pada kontrol, cendawan ditumbuhkan pada media PDA tanpa ekstrak (Rani et al. 2013).

\section{Hasil}

\section{Isolasi C.gloesporioides pada buah pepaya}

Hasil isolasi menunjukkan buah pepaya yang terserang penyakit antraknosa memiliki ciri dengan muncul bercak kecil bulat kebasahan berwarna coklat kemerahan. Bila buah bertambah masak, bulatan tadi semakin besar dan busuk cekung ke arah dalam buah. secara makroskopis yang menyerang buah pepaya pada penyimpanan memiliki ciri koloni berwarna putih dengan tepian rata, permukaan agak sedikit halus dan berbentuk bulat sedangkan secara mikroskopis memiliki konidia yang berbentuk silindris dengan ujungujung tumpul, konidiofor yang tidak bersekat, tidak bercabang dan hifa yang bersekat. Hasil isolasi dan identifikasi C.gloesporioides pada buah pepaya dapat dilihat pada (gambar 1).

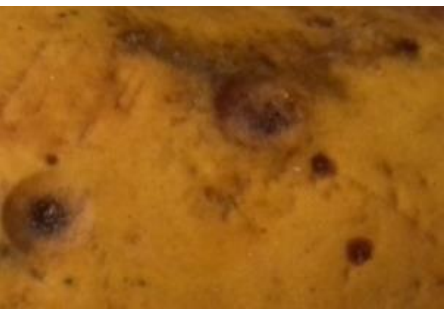

a

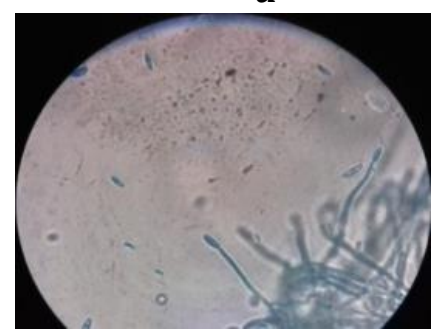

c

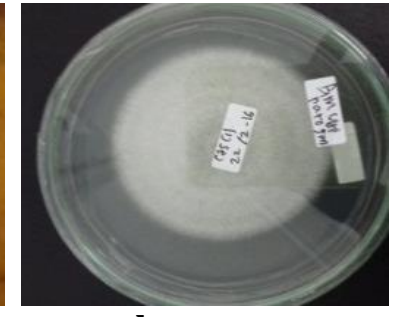

b

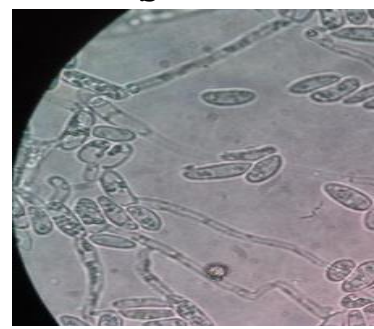

d
Gambar 1. a. Buah pepaya yang terserang antraknosa b. Koloni C.gloesporioides c. C.gloesporioides secara mikroskopis menggunakan pewarnaan d. C.gloesporioides secara mikroskopis menggunakan water agar.

\section{Patogenisitas C.gloesporioides pada buah pepaya}

Buah pepaya yang akan diuji patogenisitas yaitu sudah matang fisiologis dan tidak terdapat luka atau memar pada permukaan buahnya. Buah pepaya yang sudah menimbulkan gejala akibat penempelan C.gloesporioides, memiliki ciri berwarna coklat kemerahan yang berbentuk bulatan semakin besar dan busuk cekung ke arah dalam buah, waktu yang dibutuhkan cendawan untuk menginfeksi buah pepaya \pm 1 minggu sehingga muncul gejala. Hasil cendawan reisolasi dari buah pepaya, cendawan yang tumbuh memiliki ciri yang sama dengan cendawan hasil isolasi dari buah pepaya sebelumnya yaitu berwarna putih dengan tepi yang rata, permukaan agak sedikit halus dan berbentuk bulat. Buah pepaya yang akan diuji patogenisitas dan hasil uji patogenisitas dapat dilihat pada (Gambar 2).

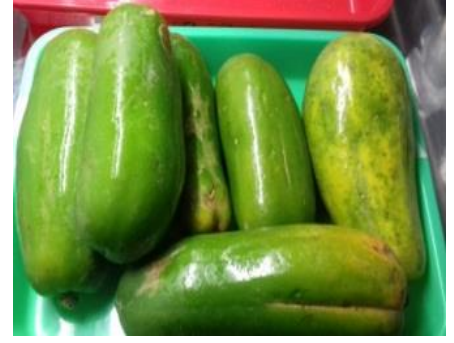

a

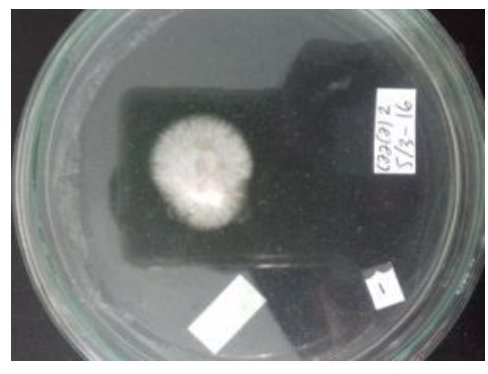

C

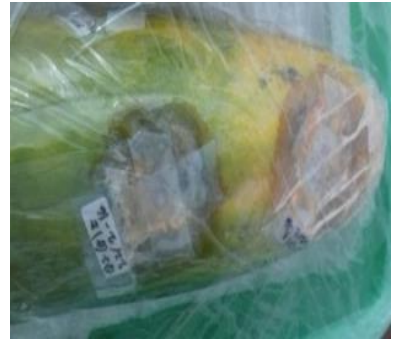

b
Gambar 2. a. Buah pepaya yang akan diuji patogenisitas b. Buah pepaya hasil uji patogenisitas c. Koloni C.gloesporioides hasil reisolasi.

Uji Efikasi Ekstrak Daun Mengkudu, Kemangi dan Jambu biji Terhadap Pertumbuhan C.gloesporioides

Ekstrak terbaik terdapat pada perlakuan ekstrak daun jambu biji yang berbeda nyata dengan perlakuan ekstrak lainnya. Pada perlakuan konsentrasi, diameter paling kecil yaitu $44.95 \mathrm{~mm}$ terdapat pada konsentrasi 30\% ekstrak daun jambu biji yang berbeda nyata dengan konsentrasi lainnya. Hasil analisis sidik ragam uji efikasi ekstrak daun mengkudu, kemangi dan jambu biji dalam menghambat pertumbuhan C.gloesporioides pada buah pepaya pada peubah diameter koloni dapat dilihat pada (Tabel 1). 
Tabel 1. Sidik ragam peubah diameter koloni C.gloeosporioides pada buah pepaya.

\begin{tabular}{cccccccc}
\hline \multirow{2}{*}{ Peubah yang diamati } & \multicolumn{2}{c}{ Ekstrak } & \multicolumn{2}{c}{ Konsentrasi } & \multicolumn{2}{c}{ Kombinasi } & \\
\cline { 2 - 6 } & F.hit & Pr $>\mathrm{F}$ & F.hit & Pr $>\mathrm{F}$ & F.hit & Pr $>\mathrm{F}$ & KK(\%) \\
\hline Diameter koloni $(\mathbf{m m})$ & $258.71^{* *}$ & $<.0001$ & $10.50^{* *}$ & $<.0001$ & $21.34^{* *}$ & $<.0001$ & 3.793189
\end{tabular}

Keterangan: tn : berpengaruh tidak nyata

* : berpengaruh nyata

**: berpengaruh sangat nyata

Tabel 2. Uji lanjut kombinasi macam ekstrak pada berbagai konsentrasi dalam menghambat pertumbuhan C.gloeosporioides pada buah pepaya.

\begin{tabular}{ccccccccc}
\hline \multirow{2}{*}{ Ekstrak } & \multicolumn{7}{c}{ Konsentrasi } & \multirow{2}{*}{ Rerata } \\
\cline { 2 - 7 } & K0\% & K10\% & K20\% & K30\% & K40\% & K50\% & K60\% & \\
\hline Mengkudu & $85.17 \mathrm{ef}$ & $88.05 \mathrm{f}$ & $87.38 \mathrm{ef}$ & $89.68 \mathrm{f}$ & $88.87 \mathrm{f}$ & $89.30 \mathrm{f}$ & $89.22 \mathrm{f}$ & 88.24 \\
Kemangi & $82.10 \mathrm{de}$ & $84.93 \mathrm{def}$ & $88.22 \mathrm{f}$ & $89.55 \mathrm{f}$ & $89.38 \mathrm{f}$ & $88.82 \mathrm{f}$ & $89.62 \mathrm{f}$ & 87.52 \\
Jambu biji & $84.66 \mathrm{def}$ & $70.99 \mathrm{c}$ & $79.48 \mathrm{~d}$ & $44.95 \mathrm{a}$ & $68.97 \mathrm{bc}$ & $64.93 \mathrm{~b}$ & $69.50 \mathrm{bc}$ & 69.07 \\
\hline Rerata & 83.98 & 81.32 & 85.03 & 74.73 & 82.40 & 81.02 & 82.78 & \\
\hline
\end{tabular}

Keterangan : Angka yang diikuti oleh huruf yang sama menunjukkan berbeda tidak nyata menurut uji Duncan (DMRT) 5\%.

Hasil uji lanjut kombinasi peubah diameter koloni pada perlakuan ekstrak daun mengkudu, kemangi dan jambu biji dalam menghambat pertumbuhan C. gloesporioides pada buah pepaya dapat dilihat pada Tabel 2 .

\section{Pembahasan}

Isolasi dan Identifikasi C.gloeosporioides pada buah pepaya

Penyakit antraknosa memiliki ciri-ciri berbentuk bulatan yang berwarna coklat kemerahan, kebasahan dan semakin lama bulatan tersebut menjadi besar dan busuk. Buah akan mudah terserang antraknosa bila permukaan buah terdapat luka. Menurut Indriyani (2008) dan Hafsah (2005) terhadap buah pepaya California, gejala pada buah yang menjelang matang muncul bercak-bercak kecil bulat kebasahan berwarna coklat kemerahan. Bila buah bertambah masak, bulatan semakin besar dan busuk cekung ke arah dalam buah.

Secara makroskopis ciri cendawan C.gloeosporioides yaitu koloni berwarna putih dengan tepian rata, permukaan agak sedikit halus dan berbentuk bulat. Menurut Hamdayanty et al. (2012), koloni cendawan yang diisolasi dari buah pepaya berupa miselium berwarna putih. Menurut Dwidjoseputro (1978), cendawan yang termasuk C.gloesporioides memiliki ciri secara makroskopis yaitu berbentuk silinder, tepi tidak rata, berwarna putih.

Secara mikroskopis memiliki konidia yang berbentuk silindris dengan ujung-ujung tumpul, konidiofor yang tidak bersekat, tidak bercabang dan hifa yang bersekat. Secara mikroskopis C.gloeosporioides menunjukkan karakteristik konidia hialin, berbentuk bulat lonjong, bersel 1 (Barnett \& Hunter (1972) dan Watanabe \& Tsuneo (1937) terbentuk pada ujung konidiofor yang sederhana (Semangun 2000). Menurut Hamdayanty et al. (2012) konidia berupa sel tunggal, hialin, dan kedua ujung konidia tumpul. Menurut Alexopoulus \& Mims (1979) dan Dwidjoseputro (1978), konidia terbentuk tunggal pada ujung-ujung konidiofor. Konidiofor pendek, tidak berwarna, tidak bercabang, tidak bersekat, kadang-kadang berbentuk agak jorong dengan penyempitan dibagian tengah, konidiofor pendek, beregresi (berkumpul).

Cendawan penyebab penyakit pada setiap buah mempunyai ciri makroskopis yang berbeda hal ini disebabkan oleh perbedaan kondisi tempat tumbuh cendawan dan tanaman inangnya. Menurut Alexopoulus \& Mims (1979), jamur Colletrotrichum sp. tidak tetap secara koloni, ciri makroskopis tergantung kondisi tempat tumbuhnya.

\section{Uji Patogenisitas}

Buah pepaya yang akan diuji terlebih dahulu dilukai. Pada umumnya kerusakan pada buah matang lebih banyak terjadi pada buah yang luka pada saat sebelum panen dan setelah panen. Menurut Agrios (2004), terdapat tiga jalan atau cara yang digunakan oleh patogen dalam melakukan penetrasi yaitu, luka, lubang alami, dan penetrasi langsung. Luka yang ada pada tanaman dapat disebabkan oleh manusia, angin, air hujan, 
atau serangan dari hama. Lubang alami yang biasa digunakan oleh patogen untuk masuk ke dalam tubuh tanaman inang antara lain, stomata, hidatoda dan lenti sel. Cara penetrasi langsung, dibutuhkan usaha dari patogen lain dengan memproduksi zat kimia berupa enzim atau toksin yang berfungsi untuk mendegradasi dinding sel dan atau merubah permeabilitas membran sel tanaman. Keadaan cuaca yang lembab sangat cocok untuk pembentukan spora dan terjadinya infeksi sehingga diameter akan cepat membesar.

Buah yang telah ditempelkan dengan isolat cendawan mulai menunjukkan gejala kerusakannya \pm 1 minggu. Menurut Abadi (2003), infeksi adalah proses patogen berhasil kontak dengan sel/jaringan rentan dan berhasil memanfaatkan nutrisi inang tersebut. Keberhasilan infeksi ditampakkan dalam bentuk gejala sakit. Lamanya sangat tergantung patogen, inang dan lingkungan yang mendukung proses tersebut. Kebanyakan infeksi terjadi antara 2-4 hari sampai beberapa minggu, namun ada yang sampai 3 tahun.

Hasil uji patogenisitas isolat cendawan yang berwarna putih dengan permukaan sedikit tebal yang diduga C.gloesporioides, menunjukkan gejala kerusakan dengan membentuk bulatan yang berwarna coklat kemerahan yang semakin lama semakin cekung kemudian lunak dan hancur. Gejala kerusakan buah pepaya hasil uji patogenisitas mirip dengan gejala penyakit antraknosa dilapangan, selain itu juga hasil reisolasi menunjukkan ciri makroskopis dan mikroskopis yang sama dengan hasil isolasi dari buah pepaya yang terserang antraknosa.

Pengaruh berbagai ekstrak daun dalam menghambat pertumbuhan C.gloeosporioides pada buah pepaya

Berdasarkan hasil penelitian bahwa perlakuan ekstrak daun jambu biji pada konsentrasi 30\% mampu menghambat pertumbuhan C.gloesporioides. Hal ini diduga bahwa daun jambu biji memiliki senyawa aktif yang mampu menghambat pertumbuhan cendawan seperti tanin, alkaloid, flavonoid, triterpenoid, saponin, minyak atsiri. Menurut Depkes (1989), daun jambu biji mengandung senyawa tanin 9-12\%, minyak atsiri, saponin, flavonoid, minyak lemak dan asam malat.

Menurut Undriani (1987), bahwa senyawa antimikroba seperti flavonoid, minyak atsiri, alkaloid, triterpenoid, saponin dan tannin dapat merusak dinding sel cendawan yang tersusun oleh senyawa kitin hingga terjadi lisis, mengubah permeabilitas membran sitoplasma sehingga sel bocor, menyebabkan denaturasi protein sel komponen dinding sel. Penghambatan intraseluler zat-zat yang terkandung mampu menghambat reaksi enzimatis, merusak molekul protein, dan asam nukleat serta menghambat sintesis asam nukleat sehingga metabolism sel cendawan terganggu dan perkembangbiakan menjadi terhambat.

Ekstrak daun mengkudu dan kemangi dengan beberapa konsentrasi tidak mampu menghambat pertumbuhan C.gloesporioides, hal ini dapat dilihat dari persentase penghambatan cendawan yang menunjukkan nilai paling kecil dibandingkan dengan ekstrak daun jambu biji. Hal ini diduga karena daun mengkudu dan kemangi tidak mengandung senyawa aktif tanin.

Faktor lain diduga pengaruh $\mathrm{pH}$ air yang digunakan pada saat pembuatan media maupun ekstrak. pH yang tidak sesuai akan memacu ataupun menghambat pertumbuhan cendawan. Menurut Mutiara (2014), faktor yang mempengaruhi pertumbuhan jamur adalah zat makanan, $\mathrm{pH}$, air, oksigen dan senyawa penghambat pertumbuhan. Menurut Yulianty (2006), pH optimal untuk pertumbuhan jamur Colletotrichum yang baik adalah $\mathrm{pH}$ 5-7. Suhu optimum untuk pertumbuhan jamur ini antara 24$30{ }^{\circ} \mathrm{C}$ dengan kelembaban relatif antara $80-92 \%$ (Mutiara 2014).

Hasil kombinasi ekstrak dan konsentrasi menunjukkan perlakuan ekstrak daun jambu biji pada konsentrasi 30\% memberikan hambatan paling baik. Hal ini dikarenakan kombinasi perlakuan ekstrak daun dengan konsentrasi saling mendukung dalam menghambat pertumbuhan C.gloesporioides pada buah pepaya.

Hal ini diduga pada media yang ditambahkan ekstrak daun jambu biji dengan penambahan konsentrasi $30 \%$ ekstrak daun jambu biji menyebabkan kerusakan pada dinding sel serta pertumbuhan cendawan tersebut dan sebaliknya. Pada ekstrak dan konsentrasi daun mengkudu dan kemangi, cendawan tumbuh dengan baik. Hal ini diduga karena syarat untuk tumbuh cendawan tersebut lebih mendukung dan makanan bagi cendawan tersebut tersedia dengan cukup serta zat yang berfungsi untuk menghambat pertumbuhannya tidak tersedia pada ekstrak daun mengkudu dan kemangi.

Pertumbuhan diameter mengalami peningkatan pada konsentrasi $40 \%$, 50\% dan $60 \%$ hal ini diduga disebabkan oleh daya difusi ekstrak dalam media yang berkurang. Menurut Sudjaswadi (2006), efektivitas senyawa antimikroba dipengaruh oleh karakter dinding sel atau membran sel dari mikroorganisme tersebut. 
Menurut Handajani \& Purwoko (2008) pertumbuhan mikroba dipengaruh oleh konsentrasi ekstrak, tingkat kelarutan ekstrak, konsentrasi mikroorganisme dan kemampuan ekstrak berdifusi dalam agar. Semakin tinggi konsentrasi ekstrak semakin rendah kelarutannya (mengental seperti gel) karena terbentuk endapan. Menurut Purnomo (2008), peningkatan konsentrasi ekstrak pada uji in-vitro tidak berbanding lurus dengan peningkatan daya hambat diduga karena adanya penurunan kemampuan ekstrak dalam menekan pertumbuhan C.capsici yang disebabkan oleh kurang optimalnya suhu pada saat perlakuan.

Pada umumnya pertumbuhan cendawan akan terhambat dengan baik pada konsentrasi dan ekstrak tanaman tertentu. Suatu media dapat menumbuhkan mikroorganisme dengan baik diperlukan persyaratan antara lain: media harus mempunyai tekanan osmosis, dan $\mathrm{pH}$ yang sesuai, media tidak mengandung zat-zat penghambat, media harus steril, dan media harus mengandung semua nutrisi yang mudah digunakan mikroba (Pelzar \& Chan 1998).

\section{Kesimpulan}

Ekstrak daun jambu biji dapat menghambat pertumbuhan C.gloesporioides pada buah pepaya. Konsentrasi ekstrak daun jambu biji 30\% memberikan daya hambat paling baik terhadap pertumbuhan C.gloesporioides pada buah pepaya.

\section{Daftar Pustaka}

Abadi LA. 2003. Ilmu Penyakit Tumbuhan. Malang: Bayumedia Publishing.

Agrios GN. 2004. Plant Pathology Edisi Ke-5 [Terjemahan]. San Diego: Academic Press,Inc.

Barnett HL, BB Hunter. 1972. Illustrated Genera of Imperfect Fungi [Terjemahan]. California: Burgess Publishing Company.

Departemen Kesehatan. 1989. Vademakum Bahan Obat Alam. Jakarta: Dirjen POM Departemen Kesehatan Republik Indonesia, hal 84-86.

Dwidjoseputro D. 1978. Pengantar Mikologi Edisi II. Bandung: Penerbit Alumni.

Hafsah S. 2005. Studi Patogen Antraknosa Pada pepaya. Bogor: Jurusan Proteksi Tanaman, IPB.

Hafsah S. 2007. Daya Gabung dan Heterosis Ketahanan Pepaya (Carica papaya L) terhadap Penyakit Antraknosa [Disertasi]. Bogor: Fakultas Pertanian, IPB.

Hamdayanty, Yunita R, Amin NN, Damayanti TA. 2012. Pemanfaatan Kitosan Untuk Mengendalikan Antraknosa Pada Pepaya
(Colletotrichum gloeosporioides) dan Meningkatkan Daya Simpan Buah. Jurnal Fitopatologi. Bogor: IPB.

Handajani NS, Purwoko T. 2008. Aktivitas ekstrak rimpang Lengkuas (Alpinia galanga) terhadap pertumbuhan Jamur Aspergilus SP. penghasil Alfa toksin dan Fusarium moniliforme. Biodiversitas. 9(3): 161.

Heyne K. 1987. Tumbuhan Obat berguna Indonesia. Jakarta: Badan Litbang Kehutanan.

Indriyani PL. 2008. Pengelolaan Kebun Pepaya Sehat. Sumatera Barat: Balai Penelitian tanaman buah Tropika.

Medica V, Ruslan, Nawawi. 2004. Telaah Fitokimia daun Kemangi (Ocimum basilicum L.) [Skripsi]. Bandung: Jurusan Farmasi, ITB.

Mutiara Dl. 2014. Pengaruh Lama Fermentasi dan Konsentrasi Ekstrak Daun Jambu Biji (Psidium guajava Linn) Terhadap Aktivitas Antioksidan Kombucha [Skripsi]. Surakarta: Program Studi Pendidikan Biologi Fakultas Keguruan dan Ilmu Pendidikan Universitas Muhammadiyah Surakarta.

Nazirah L. 2011. Pengetahuan, Sikap, Dan Tindakan Petani Dalam Pengelolaan Hama dan Penyakit Pepaya Di Kecamatan Rancabungur, Bogor [Skripsi]. Bogor: Fakultas Pertanian, IPB.

Nugraheni SA, Djauhari S, Cholil A, Utomo EP. 2014. Potensi Minyak Atsiri Serai Wangi (Cymbopogon winterianus) sebagai Fungisida Nabati terhadap Penyakit Antraknosa (Colletotrichum gloeosporioides) pada Buah Apel (Malus sylvestris Mill). Jurnal HPT. 2 (04).

Nugroho BN. 1999. Pembuatan Medium dan Inokulasi Fermentasi. Jakarta : Direktorat Teknologi Bioindustri, BPP Teknologi dan BPP Bioteknologi Industri dan Pertanian.

Pelzar JM, Chan ECS. 1998. Dasar-Dasar Mikrobiologi 2. Jakarta: Penerbit UI Press.

Purnomo D. 2008. Aplikasi getah dua genotipe pepaya betina sebagai biofungisida untuk mengendalikan penyakit antraknosa pada tanaman cabe merah besar (Capsicum annum L.) [Skripsi]. Bogor: Fakultas Pertanian, IPB.

Rahmawati A. 2009. Kandungan Fenol Tanaman Mengkudu. FK. Universitas Indonesia.

Rani PES, Efri, Prasetyo J. 2013. Pengaruh Berbagai Tingkat Fraksi Ekstrak Daun Mengkudu (Morinda citrifolia L) Terhadap Pertumbuhan Colletotrichum capsici Penyebab Penyakit Antraknosa Pada Cabai (Capsicum annum L) Secara In-Vitro. Jurnal Agrotek Tropika. 1(1).

Semangun H. 2000. Penyakit-penyakit Tanaman Hortikultura di Indonesia. Yogyakarta: UGM.

Undriani K. 1987. Pengaruh bubuk jahe (Zingiber offcinale) terhadap aktivitas pertumbuhan 
beberapa mikroba penyebab kerusakan pangan [Skripsi]. Bogor: IPB.

Watanabe, Tsuneo. 1937. Pictorial Atlas Of Soil And Seed Fungi Morphologies Of Cultured Fungi And Key To Species. Second Edition [Terjemahan]. New York: Boca Raton London New York Washington, D.C : Crc Press.
Yulianty. 2006. Pengaruh pH Terhadap Pertumbuhan Jamur Colletotrichum capsici Penyebab Antraknosa Pada Cabai ( Capsicum annum L ) Asal Lampung. Diakses Dari Http:// Www.Thechileman.Org/Guide.Disease. [Tanggal 30 April 2016]. 